\title{
Mortality of young people with cancer: clinical-epidemiological characteristics of death and emerging ethical aspects
}

\author{
Carlo Egysto Cicero-Oneto ${ }^{1}$, Guadalupe Mata-Valderrama² and Edith Valdez-Martínez ${ }^{2 *}$
}

${ }^{1}$ Department of Hematological Oncology, Hospital Infantil de México Federico Gómez, SSA; ${ }^{2}$ Health Research Coordination, IMSS, Ciudad de México, Mexico

\begin{abstract}
Objective: To describe the epidemiological, clinical, and ethical aspects of the mortality of young people with cancer in Mexico. Methods: 63 medical records from 14 to 18-year-old patients, with cancer, who died between 2011 and 2014, were reviewed to obtain epidemiological and clinical characteristics of their death. The study sites were three tertiary referral hospitals in Mexico City. Results: Of 40 young people in terminal phase, 16 (40\%) continued to receive curative treatment; of the 51 whose place of death was known, 45 (88\%) died in hospital. Of the 41 who died within 30 days of their last hospitalization, deaths were due to complications (51\%), progression of the disease (41\%), and deaths of those in palliative care $(7 \%)$. Conclusions: Oncological practice rests on what is known as a biomedical model. The results of this study suggest the urgent need for, and support the implementation of, true palliative-care services. More importantly, these findings underscore the necessity of putting the ethics of clinical practice into action, such that best practice in medicine is reinforced.
\end{abstract}

KEY WORDS: Cancer. Young people. Mortality. Epidemiology. Ethics.

\section{Introduction}

Cancer is considered to be one of the leading causes of disease and premature death in the region of the Americas ${ }^{1,2}$. In Mexico, in 2010, the population of adolescents was 21,966,049 from a total of 112,336,538 inhabitants ${ }^{3}$. Between 5,000 and 6,000 new cancer cases are estimated to occur every year ${ }^{4}$. Cancer incidence is 203 new cancer cases per million adolescents ${ }^{4}$; out of these, approximately $79 \%$ are attended to by the network of public hospitals that depend on the Ministry of Health and $21 \%$ by the Social Security system ${ }^{5}$.

There are reasons that justify this study particularly focused on adolescents. First, worldwide, unlike the group of children younger than 15 years, the incidence of cancer in adolescents (from 14 to 18 years of age) is up to $50 \%$ higher (with a different pattern of presentation $)^{5,6}$. Second, world literature reports that adolescents, in comparison with children younger than 15 years, tend to be diagnosed at more advanced stages of disease, in addition to having a poorer adherence to chemotherapeutic treatment ${ }^{7-9}$; hence, a higher incidence of treatment-associated complications is reported for this group ${ }^{10}$. Third, in developing countries, survival of pediatric patients with cancer at diagnosis is approximately $56 \%{ }^{11}$, with an estimated mortality of 5 to 7 cases per 100,000 adolescents ${ }^{11-13}$. Fourth, studies carried out in USA and Taiwan show that when outpatient palliative care is adequately provided, cancer patients prefer dying at home ${ }^{14-19}$. Fifth, palliative care is essential and should be an integral

Correspondence:

Edith Valdez-Martínez

Coordinación de Investigación en

Salud, IMSS

Centro Médico Nacional Siglo XXI

Avda. Cuauhtémoc, 330

Col. Doctores

Date of reception: 20-06-2016

Date of acceptance: 06-07-2016

C.P. 06725, Ciudad de México, México

E-mail: edith.valdez@imss.gob.mx
DOI://dx.doi.org/10.24875/GMM.M18000104
Gac Med Mex. 2018;154:1-7

Contents available at PubMed www.gacetamedicademexico.com 
range: $14-16$ years). Of the 63 adolescents, $38(60 \%)$ had secondary school and $16(25 \%)$ had primary school as highest level of education. In 36 of these adolescents (57\%), both parents acted as legal guardians, whereas in $23(37 \%)$, the mother was the sole legal guardian.

\section{Epidemiological characteristics}

In 42 adolescents (67\%), solid tumors predominated over hematological neoplasms. Table 2 shows the histologic lineages by gender. Leukemia, soft tissue sarcomas and gonadal germ cell tumors were predominant in males, whereas in females, bone tumors, especially osteosarcoma, prevailed.

Neoplasm stage or risk was mentioned in 15 (24\%) records. All neoplasms that were staged belonged to the highest risk group; i.e., high risk for lymphoblastic leukemia, and stages III and IV for solid tumors.

Of the 63 adolescents, $32(51 \%)$ were reported to be at disease progression, $19(30 \%)$ on relapse, $4(6 \%)$ on complete remission and $2(3 \%)$ on partial remission. In 6 medical records (10\%), there was evidentiary documentation of death occurred during curative treatment initiation, with no remission being documented.

Of the 63 adolescents, 33 (52\%) received curative treatment and $18(29 \%)$ were on palliative treatment (Table 3). Of the 12 cases (19\%) that abandoned treatment, 6 were on curative treatment and 6 on palliative treatment (Tables 1 and 3).

According to medical record data, overall survival (time-interval comprised between cancer diagnosis and the date of death) ranged from 1 to 536 weeks, with a median of 71 weeks (interquartile range: 35 150 weeks). Among the 63 adolescents, 31 deaths $(49 \%)$ occurred within the first 100 weeks after diagnosis, regardless of risk, stage of disease or type of treatment received.

The place of death was recorded in 51 (81\%) of the 63 records; the remaining 12 records corresponded to adolescents who abandoned treatment. Of these 51, $45(88 \%)$ died at the hospital and $6(12 \%)$ at home. More precisely, all adolescents (33/33) who were receiving curative treatment died at the hospital, whereas $12(66 \%)$ of 18 who received palliative care died at the hospital and the remaining 6 at home (Table 3).

\begin{tabular}{|c|c|c|c|c|}
\hline \multirow[t]{2}{*}{ Type of Neoplasm } & \multicolumn{2}{|c|}{ Gender } & \multirow{2}{*}{\multicolumn{2}{|c|}{$\begin{array}{r}\begin{array}{r}\text { Total } \\
(n=63)\end{array} \\
(n=6\end{array}$}} \\
\hline & $\begin{array}{c}\text { Male } \\
(n=41)\end{array}$ & $\begin{array}{l}\text { Female } \\
(n=22)\end{array}$ & & \\
\hline Leukemia & 11 & 6 & $\stackrel{2}{2}$ & 17 \\
\hline Acute lymphoblastic leukemia & 7 & 4 & है & 11 \\
\hline Acute myeloid leukemia & 3 & 2 & 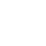 & 5 \\
\hline Chronic granulocytic leukemia & 1 & 0 & & 1 \\
\hline Lymphomas & 3 & 1 & $\check{\circlearrowright}$ & 4 \\
\hline Hodgkin's lymphomas & 0 & 0 & $\overline{\underline{n}}$ & 0 \\
\hline Non-Hodgkin lymphomas & 3 & 1 & 을 & 4 \\
\hline CNS tumors & 10 & 5 & $\subsetneq$ & 15 \\
\hline Astrocytoma & 2 & 0 & $\frac{0}{c}$ & 2 \\
\hline Medulloblastoma & 2 & 2 &. $\bar{n}$ & 4 \\
\hline Ependimoma & 1 & 1 & $\frac{5}{2}$ & 2 \\
\hline CNS germ cell tumors & 3 & 1 & $\frac{c}{d}$ & 4 \\
\hline CNS primitive neuroectodermal tumor & 2 & 1 & $\frac{5}{2}$ & 3 \\
\hline Bone tumors & 7 & 9 &.$\overline{0}$ & 16 \\
\hline Osteosarcoma & 4 & 8 & 르 & 12 \\
\hline Ewing's sarcoma & 3 & 1 & 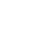 & 4 \\
\hline Soft tissue sarcoma & 3 & 0 & 울 & 3 \\
\hline Rhabdomyosarcoma & 2 & 0 & 3 & 2 \\
\hline Hemangioendothelioma & 1 & 0 & 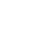 & 1 \\
\hline Germ cell tumors & 3 & 0 & ○ & 3 \\
\hline Testicular germ cell tumor & 3 & 0 & $\frac{0}{0}$ & 3 \\
\hline Other & 4 & 1 & ¿ & 5 \\
\hline Malignant melanoma & 1 & 0 & $\stackrel{d}{\circlearrowright}$ & 1 \\
\hline Mucus-producing adenocarcinoma & 1 & 0 & 은 & 1 \\
\hline Neuroblastoma & 0 & 1 & $\frac{0}{2}$ & 1 \\
\hline Paraganglioma & 1 & 0 & 足 & 1 \\
\hline Hepatoblastoma & 1 & 0 & $\varepsilon$ & 1 \\
\hline
\end{tabular}

\section{Clinical characteristics}

Of the 41 adolescents who died during the 30 days of their last hospitalization, 21 deaths $(51 \%)$ were due to complications, $17(41 \%)$ due to disease progression and 3 occurred on palliative care.

Of the 63 adolescents, 37 (59\%) were hospitalized at the Oncology Department, $14(22 \%)$ were admitted to the pediatric intensive care unit, $7(11 \%)$ remained 
Table 3. Type of treatment provided to adolescents with terminal phase criteria

\begin{tabular}{|c|c|c|c|c|c|c|}
\hline \multirow[t]{3}{*}{ Type of treatment } & \multicolumn{4}{|c|}{ Total number of adolescents $(n=63)$} & & \\
\hline & \multicolumn{2}{|c|}{ Terminal phase } & \multicolumn{2}{|c|}{ Place of death occurrence } & $\stackrel{\infty}{\leftarrow}$ & \\
\hline & $\begin{array}{c}\text { Yes } \\
(n=40)\end{array}$ & $\begin{array}{c}\text { No } \\
(n=23)\end{array}$ & $\begin{array}{l}\text { Hospital } \\
(n=45)\end{array}$ & $\begin{array}{l}\text { Home } \\
(n=6)\end{array}$ & \multicolumn{2}{|c|}{$\begin{array}{l}\text { Unknown } \\
(\mathrm{n}=12)\end{array}$} \\
\hline Curative & 33 & 10 & 23 & 0 & \multirow{3}{*}{ 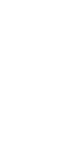 } & 0 \\
\hline Curative treatment abandonment & 6 & 6 & 0 & $n / d$ & & 6 \\
\hline Palliative & 18 & 18 & 0 & 6 & & 0 \\
\hline Palliative treatment abandonment & 6 & 6 & 0 & $\mathrm{n} / \mathrm{d}$ & $\frac{\check{\alpha}}{\alpha}$ & 6 \\
\hline
\end{tabular}

at the Emergency Department, $3(5 \%)$ were admitted to the Surgery Department, one (2\%) to the Ophthalmology Department and one (2\%) to the Chemotherapy Unit.

Although in each and every one of the cases the healthcare team involved in medical care (during the last hospitalization) was led by an oncologist, $38(60 \%)$ of the 63 medical records also had medical notes from another medical specialist. The Pain Clinic was involved in 50 cases (72\%). In 40 records (58\%), there were notes from the psychology department, and in $37(54 \%)$, there were notes from Social Work.

Among the 63 adolescents with cancer, the reason for admission in the last in-hospital stay was the presence of complications for 37 (59\%) and/or to receive chemotherapy as part of their treatment in $26(41 \%)$ (Table 4).

Of the 43 deaths due to complications, 37 were the reason for admission in the last hospitalization, and the remaining 6 were recorded in adolescents who were admitted to receive chemotherapy. The type of documented complications in the 43 recorded deaths were: infectious, 34 (79\%); compressive, 5 (12\%); hematologic, $3(7 \%)$ and metabolic, one $(2 \%)$. Of the 34 infectious complications, 9 (26\%) were due to septic shock, $9(26 \%)$ to fever and neutropenia, $6(18 \%)$ to pneumonia and $3(9 \%)$ to sepsis (Table 4 ).

Infectious complications were predominant in adolescents with diagnoses of leukemia $(38 \%, 13 / 34)$ and central nervous system (CNS) tumors $(29 \%, 10 / 34)$. Compressive complications were more common in adolescents with diagnoses of lymphomas $(60 \%, 3 / 5)$. Hematologic complications were only found in adolescents with leukemia (3/3). The only metabolic complication was documented in an adolescent with a CNS tumor (Table 4).

Of the 43 adolescents who experienced some type of complication, it was the cause of death for $32(74 \%)$.
The 11 remaining patients died due to disease progression or treatment abandonment. Complications occurred more commonly in adolescents with leukemia $(50 \%, 16 / 32)$, CNS tumors $(16 \%, 5 / 32)$ and bone tumors (16\%, 5/32) (Table 4).

The therapeutic measures employed in the treatment of complications were: chemotherapy with curative purposes $(86 \%, 37 / 43)$, blood product transfusion $(44 \%, 19 / 43)$, assisted mechanical ventilation $(46 \%$, $20 / 43$ ), tumor resection surgery with curative purposes $(30 \%, 13 / 43)$ and radiotherapy with curative purposes $(9 \%, 4 / 43)$ (Table 5$)$.

One or more terminal phase criteria were found in 40 of the 63 medical records (63\%). The terminal phase criteria most commonly used by oncologists to refer to this medical condition in the 63 adolescents were: "advanced, progressive and incurable disease", $35(56 \%)$; "lack of reasonable possibilities of response to specific treatment", 29 (46\%); "presence of numerous problems" or "presence of multiple and intense symptoms or multifactorial changing symptoms", 25 (40\%); "high emotional impact closely related to imminent death (referred or not explicitly)", on the adolescents, their relatives and on their medical team, $6(10 \%)$; and prognosis of "poor quality of life for the next 6 months", 24 (38\%).

Among those 40 adolescents, in 29 (73\%), the disease was on progression and in $11(28 \%)$ it was on relapse at the moment of death. There was also documentation indicating that $24(60 \%)$ were receiving palliative treatment, while $16(40 \%)$ continued on treatment with curative purposes. Treatment of pain and infections, blood transfusions and ventilatory support were the most widely used supportive measures, in addition to chemotherapy (Table 5).

\section{Discussion}

The results of the present study show that the pattern of death in Mexico by type of tumor (leukemia, 
Table 4. Reason for hospitalization, type of complications and cause of death in adolescents with cancer $(n=63)$

\begin{tabular}{|c|c|c|c|c|c|c|c|c|c|}
\hline \multirow[t]{2}{*}{ Item } & \multicolumn{7}{|c|}{ Type of cancer } & \multirow{2}{*}{\multicolumn{2}{|c|}{\begin{tabular}{l|l}
$\underbrace{\infty}_{0}$ & Total \\
$\frac{N}{1}$ &
\end{tabular}}} \\
\hline & $\begin{array}{l}\text { Leukemia } \\
(n=17)\end{array}$ & $\begin{array}{c}\text { CNS } \\
\text { tumors } \\
(n=15)\end{array}$ & $\begin{array}{l}\text { Lymphomas } \\
\qquad(n=4)\end{array}$ & $\begin{array}{c}\text { Bone } \\
\text { tumors } \\
(n=16)\end{array}$ & $\begin{array}{l}\text { Soft tissue } \\
\text { sarcomas } \\
\quad(n=3)\end{array}$ & $\begin{array}{c}\text { Germ cell } \\
\text { tumors } \\
(n=3)\end{array}$ & $\begin{array}{l}\text { Others } \\
(n=5)\end{array}$ & & \\
\hline \multicolumn{8}{|l|}{ Reason for hospitalization } & $\frac{\epsilon}{\sigma}$ & \\
\hline Chemotherapy & 5 & 6 & 3 & 7 & 2 & 1 & 2 & $\varepsilon$ & 26 \\
\hline Cardiogenic shock & 0 & 0 & 0 & 0 & 1 & 0 & 0 & $\bar{d}$ & 1 \\
\hline Septic shock & 2 & 2 & 1 & 3 & 0 & 0 & 1 & () & 9 \\
\hline Seizures & 0 & 1 & 0 & 0 & 0 & 0 & 0 & & 1 \\
\hline Respiratory failure & 0 & 0 & 0 & 1 & 0 & 1 & 0 & 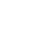 & 2 \\
\hline Pain & 0 & 0 & 0 & 1 & 0 & 0 & 0 & ๘ँ & 1 \\
\hline Fever and neutropenia & 2 & 3 & 0 & 3 & 0 & 0 & 1 & $\frac{5}{n}$ & 9 \\
\hline Arterial hypertension & 0 & 0 & 0 & 0 & 0 & 0 & 1 & 을 & 1 \\
\hline Pneumonia & 3 & 1 & 0 & 1 & 0 & 1 & 0 & కై & 6 \\
\hline Panhypopituitarism & 0 & 1 & 0 & 0 & 0 & 0 & 0 & 0 & 1 \\
\hline Sepsis & 2 & 1 & 0 & 0 & 0 & 0 & 0 & 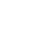 & 3 \\
\hline Hemorrhagic syndrome & 1 & 0 & 0 & 0 & 0 & 0 & 0 & $\stackrel{4}{\circ}$ & 1 \\
\hline Infiltrative syndrome & 2 & 0 & 0 & 0 & 0 & 0 & 0 & $\subsetneq$ & 2 \\
\hline \multicolumn{10}{|l|}{ Type of complication } \\
\hline Infectious & 13 & 10 & 1 & 7 & 0 & 1 & 2 & $\frac{\varepsilon}{\frac{6}{0}}$ & 34 \\
\hline Compressive & 0 & 0 & 3 & 1 & 1 & 0 & 0 & $\stackrel{1}{2}$ & 5 \\
\hline Hematologic & 3 & 0 & 0 & 0 & 0 & 0 & 0 & $\frac{c}{a l}$ & 3 \\
\hline Metabolic & 0 & 1 & 0 & 0 & 0 & 0 & 0 & \pm & 1 \\
\hline No complications & 1 & 4 & 0 & 8 & 2 & 2 & 3 & $\frac{5}{3}$ & 20 \\
\hline \multicolumn{10}{|l|}{ Cause of death } \\
\hline Disease progression & 1 & 9 & 2 & 7 & 1 & 2 & 2 & 는 & 24 \\
\hline Complication & 16 & 5 & 2 & 5 & 1 & 1 & 2 & 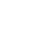 & 32 \\
\hline No data & 0 & 1 & 0 & 4 & 1 & 0 & 1 & \pm & 7 \\
\hline
\end{tabular}

CNS: central nervous syndrome.

Table 5. Medical treatment modalities of employed during adolescents with cancer last hospitalization $(n=63)$

\begin{tabular}{lll}
\hline Treatments & Modality & $\mathbf{n}$ \\
\hline Curative & Chemotherapy & 37 \\
& Mechanical ventilation & 20 \\
& Blood product transfusion & 19 \\
& Surgery & 13 \\
& Radiotherapy & 4 \\
Supportive & Pain management & 62 \\
& Infection management & 47 \\
& Blood product transfusion & 45 \\
& Mechanical ventilation & 31 \\
& Chemotherapy & 20 \\
& Parenteral nutrition & 14 \\
\hline
\end{tabular}

bone tumors and CNS tumors) coincides as such with reports in national surveys ${ }^{24}$ and with the pattern for leukemia and bone tumors in the USA ${ }^{25}$. All medical records that had the cancer stage or risk recorded belonged to adolescents at higher risk of relapse.
Treatment with chemotherapy was the main therapeutic tool, not only for adolescents with treatment for curative purposes, but also for those considered by the oncologist to be on palliative treatment. Of note, of the 40 adolescents with terminal phase criteria, $40 \%$ continued to receive treatment with curative purposes in spite of the low possibilities of short-term survival. This might explain the predominance of adolescents who died from infectious complications. The literature describes that the more intense chemotherapy is, the longer the time of immunosuppression will be and, therefore, the risk for infection will be higher ${ }^{10}$. Curative treatments per se presuppose certain quality of life values and criteria: assessing the harm that results from continuing chemotherapy with curative purposes when the probabilities of cure are known to be low, is a quality of life judgement ${ }^{26}$.

The medical record is a legal document ${ }^{27}$ where each one of the actions carried out by medical personnel is recorded; however, in nearly all records in this study, it was difficult for the moment at which the oncologist established that the cancer was no longer curable to be identified, as well as the moment palliative treatment was initiated, because the oncologist omitted such 
specifications in the patient record. In the intentional search for terminal phase criteria ${ }^{28}$ in patient evolution medical notes, one or several terminal phase criteria were documented in most cases. The two more commonly used criteria were: "advanced, progressive and incurable disease" and "lack of reasonable possibilities of response to specific treatment". In spite of these elucidations, none of the oncologists considered these terminal phase criteria to decide the type of treatment the adolescents were to receive. With these facts in sight, these acts are prima facie maleficent, and reflecting on the nature and purpose of the physician's work becomes necessary.

The obligation to benefit others is not what philosopher Immanuel Kant called an absolute moral obligation ${ }^{26}$. Several moral obligations limit the principle of beneficence. The most obvious is the moral obligation not to harm, which derives from the necessity to weigh expected harm against expected benefit of a treatment to be instituted ${ }^{26}$. Oncologists' poor communication skills can also harm their patients and/or their caregivers $^{26,29}$. Respect of the autonomy of those whom oncologists try to help is another of the moral obligations that limit the principle of beneficence ${ }^{26}$. Oncologists, and doctors in general, are often ready to assume that they know, without asking what's best for their patients, and even that they know what their patients and/or their caregivers want ${ }^{29}$. Qualitative studies in this area are therefore necessary in order to examine how oncologists' particular values, either personal or professional, manifest themselves in clinical practice during doctor-patient and/or caregivers meetings.

Our findings also indicate that therapeutic management was essentially complemented with pain management, antibiotics and blood product transfusion. The physicians more commonly involved in the treatment were oncologists, followed by infectologists, emergency physicians and intensivists. In half the medical records reviewed in this study, participation of other healthcare professionals, such as psychologists and social workers, was documented. Participation of thanatologists and/or priests was only found in three records. All this suggests that the biomedical model ${ }^{30}$ prevails in the therapeutic management of cancer: first, mind and body can be separately treated, secondly, physicians can act as engineers by "repairing only what is required" and, thirdly, explanations about the disease are focused on biological changes, avoiding psychological and social changes.
Current regulations of hospitals belonging to the Mexican healthcare system establish that "the doctor will provide palliative care since the moment terminal stage of disease is diagnosed and the patient has been informed on the palliative care existing options..." ${ }^{31}$. Changes in regulations are ethically desirable in order for palliative care to be provided at all stages of the disease. This way, recently (December 2014), the Ministry of Health issued an AGGREEMENT establishing that "palliative care must be provided both to patients on terminal phase and to people requiring pain relief, and to those who suffer from a symptomatic disease that is limiting for life, emphasizing that treatments for pain relief do not exclude curative care"21.

The hospital was the place where the highest number of deaths occurred, a situation that is explained by different reasons: continuation of aggressive chemotherapy during the terminal phase, lack of an outpatient palliative care department and lack of residences for terminally ill patients (hospices) at the national level. In other countries, such as USA and Taiwan, where there are true palliative care departments, both parents and doctors prefer home as the ideal place for the death of adolescent patients with cancer ${ }^{14-19}$.

The scenario was reconstructed with data from medical records; it is highly probable that they did not describe in detail the meetings between oncologist/ healthcare professional and adolescent/parents. However, this study provides a first view of oncologists' usual clinical practice during the terminal phase in adolescents with cancer in Mexico. The participating hospitals are centers of care specialized in oncologic conditions, which act as referral hospitals for the entire country, hence the study reflecting the situation in Mexico, as an example of Latin American countries.

\section{Conclusions}

Oncology practice rests on what is known as the biomedical model. From the oncologist's perspective, trying to prolong life is more important than the quality of life of those with cancer. The data here presented support the urgent need to implement real palliative care services, but more importantly, there is the impetus of putting clinical practice ethics into action and thereby reinforce good medical practice.

\section{Acknowledgements}

We are grateful, for their participation in the collection of data for this study, with Beatriz Marcos López 
and Mariana Ponce Gutiérrez. We would also like to express our gratitude to Prof. Teresa Tiro Sánchez and Guillermina Romero for their collaboration to the fulfillment of this study.

\section{References}

1. Organización Mundial de la Salud [Internet]. Temas de Salud. Enfermedades crónicas [fecha de última actualización: 2018]. Disponible en: http://www.who.int/topics/chronic_diseases/es/.

2. Instituto Nacional de Estadística y Geografía (INEGI) [Internet]. Estadísticas con propósito del día mundial contra el cáncer [fecha de última actualización: 1 febrero 2017]. Disponible en: http://www.inegi.org.mx/ saladeprensa/aproposito/2017/cancer2017 Nal.pdf

3. Instituto Nacional de Estadística y Geografía (INEGI) [Internet]. Censo Nacional de Población 2010, estadística por grupos de edad según sexo, 1950 a 2010. Disponible en: http://www3.inegi.org.mx/sistemas/temas/ default.aspx?s=est\&c=17484

4. Centro Nacional para la Salud de la Infancia y la Adolescencia (CENSIA). Comisión Nacional de Protección Social en Salud a través del Fondo de Protección Contra Gastos Catastróficos en México. 2015. Disponible en https://www.gob.mx/salud/censia/articulos/cancer-infantil-en-mexico-130956?state=published

5. Centro Nacional para la Salud de la Infancia y la Adolescencia (CENSIA): Comportamiento Epidemiológico del cáncer en menores de 18 años. México 2008-2014, Secretaría de Salud, Disponible en: http://censia. salud.gob.mx/contenidos/descargas/cancer/20160601_Boletin-2014 SEDP12sep16 4.pdf

6. DeSantis CE, Lin CC, Mariotto AB, et al. Cancer treatment and survivorship statistics, 2014. CA Cancer J Clin. 2014;64(4):252-71.

7. Festa RS, Tamaroff MH, Chasalow F, et al. Therapeutic adherence to oral medication regimens by adolescents with cancer. I. Laboratory assessment. J Pediatr. 1992;120:807-11.

8. Tamaroff MH, Festa RS, Adesman AR, et al. Therapeutic adherence to oral medication regimens by adolescents with cancer. II. Clinical and psychological correlates. J Pediatr. 1992;120:813-7.

9. Tebbi CK. Treatment compliance in childhood and adolescence. Cancer. 1993;71(Suppl 10):3441-9.

10. Alexander $\mathrm{S}$, Walsh $\mathrm{T}$, Freifeld $\mathrm{A}$, et al. Infectious Complications in $\mathrm{Pe}-$ diatric Cancer Patients. En: Pizzo P, Poplack D (Eds). Principles and Practice of Pediatric Oncology. Philadelphia: Lippincott Williams \& Wilkins Publishers; 2001. 786-813.

11. Centro Nacional para la Salud de la Infancia y la Adolescencia (CENSIA). Dirección General de Epidemiología. Sistema Estadístico Epidemiológico de las Defunciones (SEED). 2015. Disponible en: http://censia.salud.gob. $\mathrm{mx} /$ contenidos/cancer/cancer infantil.html

12. Escamilla-Santiago R, Narro-Robles J, Fajardo-Gutiérrez A, et al. Tendencia de la mortalidad por cáncer en niños y adolescentes según grado de marginación en México (1990-2009). Salud Pública de México. 2012;54(6):587-94

13. Smith MA, Gurney JG, Ries LA. Cancer in adolescents 15 to 19 years old. En: Ries LA, Smith MA, Gurney JG (Eds). Cancer incidence and survival among children and adolescents: United States SEER Program 1975-1997. Bethesda: National Cancer Institute, SEER Program; 1999.
14. Jacobs S, Perez J, Cheng YI, et al. Adolescent end-of-life preferences and congruence with their parents' preferences: results of a survey of adolescents with cancer. Pediatr Blood Cancer. 2015;62(4):710-4.

15. Chen CH, Lin YC, Liu LN,et al. Determinants of preference for home death among terminally ill patients with cancer in Taiwan: a cross-sectional survey study. J Nurs Res. 2014;22(1):37-44.

16. Tzuh Tang S, Hung YN, Liu TW, et al. Pediatric end-of-life care for Taiwanese children who died as a result of cancer from 2010 through 2006. J Clin Oncol. 2011;29(7):890-4.

17. Kassam A, Skiadaresis J, Alexander S, et al. Parent and clinician preferences for location of end-of-life care: home, hospital or freestanding hospice. Pediatr Blood Cancer. 2014;61(5):859-64.

18. Wilson DM, Cohen J, Deliens L, et al. The preferred place of last days: results of a representative population-based public survey. J Palliat Med. 2013;16(5):502-8

19. Tang ST, Chen CC, Tang WR, et al. Determinants of patient-family caregiver congruence on preferred place of death in Taiwan. $J$ Pain Symptom Manage. 2010;40(2):235-45.

20. Centro Nacional de Excelencia Tecnologica en Salud (CENETEC) [Internet]. Guías de prácticas clínicas. Cuidados Paliativos. Consejo de Salubridad General. 2011. Disponible en: http://www.cenetec.salud.gob. mx/descargas/gpc/CatalogoMaestro/445_GPC_Cuidados_paliativos/ GER_Cuidados_Paliativosx1x.pdf

21. Consejo de Salubridad General. Diario Oficial de la Federación. Acuerdo por el que el Consejo de Salubridad General declara la Obligatoriedad de los Esquemas de Manejo Integral de Cuidados Paliativos, así como los procesos señalados en la Guía del Manejo Integral de Cuidados Paliativos. 2014. Disponible en: http://www.csg.gob.mx/descargas/ pdfs/2015/Acuerdo_CSG_esquema_cuidados_paliativos.pdf

22. Allende S, Montes de Oca B, Nakashima Y. Atlas de Cuidados Paliativos Latinoamérica, México. 2014. Disponible en http://www.paliativossinfronteras. com/upload/publica/ATLAS-CUIDADOS-PALIATIVOS-LATIN-MEXICO.pdf

23. Allende-Pérez $S$, Verástegui-Avilés $E$, Mohar-Betancourt $A$, et al. Incorporación de los cuidados paliativos al Plan Nacional de Cáncer: consenso. Gac Mex Oncol. 2013;12(4):213-22.

24. Fajardo-Gutiérrez A, Juárez-Ocaña S, González-Miranda G, et al. Incidence of cancer in children residing in ten jurisdictions of the-Mexican Republic: Importance of the Cancer Registry (a population based study). BMC Cancer. 2007;7:68

25. Linet MS, Ries LAG, Smith MA, et al. Cancer surveillance series: Recent trends in childhood cancer incidence and mortality in the United States. J Natl Cancer Inst. 1999;91:1051-8.

26. Beauchamp TL, Childress JF. Principles of Biomedical Ethics. 7. ${ }^{\text {a }}$ Edición. New York: Oxford University Press; 2013.

27. Norma Oficial Mexicana NOM-004-SSA3-2012, del expediente clínico [Internet]. Ciudad de México: Diario Oficial de la Federación; 2016. Disponible en: http://dof.gob.mx/nota detalle.php?codigo $=5272787 \&$ fecha $=15 / 10 / 2012$

28. Guía de cuidados paliativos [Internet]. Madrid: Sociedad Española de Cuidados Paliativos (SECPAL); 2014. Disponible en: http://www.secpal. com/2-definicion-de-enfermedad-terminal

29. Lain-Entralgo P. La relación médico-enfermo: historia y teoría. Madrid: Editorial Alianza; 2003

30. Nettleton S. The sociology of health and illness. Cambridge, UK: Polity Press; 2006.

31. Guía de referencia rápida. Cuidados Paliativos. Guía de Práctica Clínica GPC. Catálogo maestro de guías de práctica clínica: IMSS-440-10 [Internet]. Instituto Mexicano del Seguro Social; 2011. Disponible en: http://www.imss.gob.mx/sites/all/statics/guiasclinicas/440GRR.pdf. 